\title{
A Comparative Study on Forest Soil Microbial Diversity and Biomass in Nilgiri Biosphere of Southern India
}

\author{
P.G. Kavitha ${ }^{1 *}$, A. Sudha ${ }^{1}$, P. Ahila Devi and K. Kumaran ${ }^{2}$ \\ ${ }^{1}$ Centre for Plant Protection Studies, Tamil Nadu Agricultural University, Coimbatore, India \\ ${ }^{2}$ Forest College and Research Institute, Mettupalayam, India \\ *Corresponding author
}

\section{Keywords}

Forest ecosystem, Microbial diversity, Bacteria, Fungi, Actinomycetes, Fungal feeding nematodes, Bacterial feeding nematodes

Article Info

Accepted: 26 August 2020 Available Online: 10 September 2020

\section{A B S T R A C T}

It is well-known that Nilgiri forest biosphere in India contains high microbial biodiversity of bacteria, fungi, actinomycetes and nematodes that play an important role in the ecosystem. The present investigation was carried out in the Nilgiri forest ecosystem in the division of North nilgiris, Tamil Nadu, India during 2017-2020 to evaluate the microbial diversity of undisturbed forest soil in two different altitudes viz., Kallar and Ooty with comparison of agro-ecosystem and polluted ecosystem and in four different seasons viz., summer (S1), pre-rainy (S2), post rainy (S3) and winter (S4). Representative soil samples were collected at four different depths $(0-15,15-30,30-45$ and $45-60 \mathrm{~cm})$ during four different seasons (summer, pre-rainy, post-rainy and winter) from all the ecosystem areas of Nilgiri forest ecosystem and were analysed for their availability for population dynamics. Samples taken during post rainy season recorded highest fungal population of $178 \times 10^{5} \mathrm{CFU} / \mathrm{g} / \mathrm{soil}$ in the kallar forest ecosystem as compared to the polluted ecosystem and lowest population for bacteria and actinomycetes. The major bacterial genera found in diversity study are occupied by Bacillus and Pseudomonas, which can survive in high temperature $\left(75 \times 10^{5} \mathrm{CFU} / \mathrm{g} / \mathrm{soil}\right)$ in summer season. Most of the population $\left(>75 \times 10^{5}\right.$ $\mathrm{CFU} / \mathrm{g} / \mathrm{soil}$ ) of fungal genera were found in low temperature and high relative humidity in Post rainy and winter season (Acrostalagmus, Polyporus, Phelliinus, Trichoderma, Aspergillus spp., Alternaria). In one gram of soil, population of bacterial feeding nematodes (Rhabditis sp. and Acrobeles sp.) dominated in lower altitudes of Kallar which resulted in higher rate of decomposition. Fungal feeding nematodes (Aphelenchus sp and Aphelenchoides sp.) were more in higher altitudes with soil having acidic $\mathrm{pH}$ due to leaching effect favored the growth of fungus. The conclusion drawn from the present study showed an increase in fungal population and fungal feeding nematode population at higher altitudes and reduction in bacterial and actinomycetes population in all the four ecosystems and all the microbial population were highest in post rainy seasons when compared to prerainy, summer and winter seasons. 


\section{Introduction}

Life on the earth is contained with the biosphere which is recognized as a vast and highly complex system made up of millions of genus and species that occupy virtually all the earth's terrestrial and aquatic surfaces. Soil is one of the most diverse habitat on earth and contains one of the most diverse groups of living organisms. The soil microorganisms play an important role in energy flow, nutrient cycling and organic matter turnover in terrestrial ecosystems (Bauhus and Khanna, 1999). The perceived values of soil communities as ecological indicators will be increased by establishing their functional links to ecosystem processes (Debruyn, 1997), determining a hierarchy of geographic scale (Neher et al., 1998) and measuring their utility across boundaries. Biodiversity in soil system is high relative to above and below ground systems (Giller, 1996) form a particular diverse component of the soil biography (Lawton et al., 1996).

The vegetation of the nilgiri forest ecosystem is characteristic of sandy coastal areas, with the prevailing species being Dalbergia Tectona grandis, Spathodeacam panulata, Jacaranda mimosifolia, Grevillea robusta, Pongamia pinnata and Kijelia pinnata. Although, now discontinuous due to deforestation, it is globally one of the most biodiverse ecosystems, containing more than $60 \%$ of the flora of the world (Faoro et al., 2010). Being self-sustaining systems, microorganisms play an important role in the decomposition of organic matter, mineralization of organic compounds and making nutrients available to plants (McGuire et al., 2012). However, populations of microorganisms and their activities can be influenced by changes in the physio and chemical characteristics of the soil (Costa et al., 2012). According to Fan et al., (2006), the total number of bacteria is positively correlated with the organic matter content of the soil. As the micro-organisms are directly involved in the cycling of nutrients in the soil, it is important to quantify them to indicate how these processes are occurring in ecosystems and are affecting soil quality (Hafich et al., 2012). The influence of the ecosystem on the number of bacteria (Silva et al., 2008), fungi (Costa et al., 2012) and actinomycetes (Ravikumar et al., 2011) has shown great variability. Nematodes (freeliving and plant-parasitic) may be the most useful group for community indicator analysis because more information exists on their taxonomy and feeding roles (Yeates, 1987) than does for other mesofauna. Soil nematodes can be placed into at least five functional or trophic groups (Yeates et al., 1993), and they occupy a central position in the detritus food web. Due to the scarcity of information about the functional role and participation of micro-organisms in coastal ecosystems, the objective of the present study was to analyse seasonal variation in microbial populations and the activities. Forest fire is also degraded the Nilgiri Biosphere Reserve every year.

However, the impact of decreasing the population of flora and fauna, which has been altering the soil microbial properties and it, has not been carried out so far (Saravanan et al., 2013). Keeping the above points in view the present study has been done with an aim to compare the population dynamics of fungi bacteria, actinomycetes and nematodes in comparison of four different ecosystem during summer, pre-rainy, post-rainy and winter seasons. The soil inhabiting microbes from two different altitude zones of Nilgiri forest with a comparative study of the microbial fauna at two different altitude zone (agro ecosystem in eastern block of Tamil Nadu Agricultural university and polluted soil of Ukkadam (town area in Coimbatore district) to assess the role of microbes as 
indicators of soil conditions and effects of altitude on microbial communities.

\section{Materials and Methods}

\section{Survey in selected forests of Nilgiris}

The details of the field and laboratory studies conducted and the methods followed are presented here. The present study were carried out in different locations viz., AgroEcosystem (Eastern block, $11^{\circ} 00^{\prime} 28.9^{\prime \prime} \mathrm{N}$, 76 56'02.4'E), forest ecosystem (Kallar, 11 $\left.{ }^{\circ} 19^{\prime} 54.1^{\prime \prime N}, \quad 76^{\circ} 54^{\prime} 01.9^{\prime \prime} \mathrm{E}\right), \quad$ forest

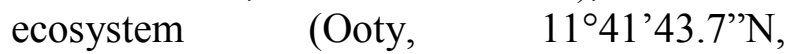
76 69'75.4'E) and polluted ecosystem (Ukkadam, 1059'12.3’N, 7658'07.4’E) section of the Nilgiris Range. Soil is generally acidic in reaction and the $\mathrm{pH}$ ranges from 5.0 to 6.5. The soil is classified into loamy brown which is rich in organic matter. A preliminary survey was conducted in selected forests of Nilgiris viz., Kunjapanai, Kotagiri and, Ooty in the second fortnight of November, 2017 to determine the occurrence of microbial community and nematodes in forest soils.

A second phase of survey was done during November 2018 in Kallar, Burliyar, Katteri, Conoor and Aravangadu. During the survey, soil and root samples were collected randomly in the forests and from tree species such as Tectona grandis, Spathodea campanulata, Jacaranda mimosifolia, Grevillea robusta, Pongamia pinnata and Kijelia pinnata with an aim of understanding the distribution and occurrence of the microbial diversity and nematode diversity and their role in soil health in the forest soils.

Since the forest ecosystem is totally undisturbed by human activities, the soil samples were filled with more of organic matter (Somasundaram, 2005). Sampling inside the forests was done with prior permission from the State Forest Department.

\section{Collection of soil samples}

\section{Estimation of microbial population}

Soil samples were collected at $0-15 \mathrm{~cm}$ depth from the experimental site and analyzed for microbial population and enumeration was done using the serial dilution techniques of Parkinson et al., 1971). Soil microbial analysis was done for enumeration of bacteria, fungi and actinomycetes population using serial dilution $10^{8}, 10^{5}$ and $10^{2}$, respectively and in appropriate medium (Nutrient Agar, Rose Bengal Agar and Ken Knights Agar) in sterile plates. The composition of each medium is given below. Enumeration was done after 24 hours for bacteria, 48 hours for fungi and six days for actinomycetes. Composition of nutrient media used for soil microbial analysis: i. BacteriaNutrient Agar medium (g lit-1): Peptone 5.0, beef extract 3.0, $\mathrm{NaCl} 5.0$, agar 20 and distilled water $1000 \mathrm{ml}$, ii. Fungi- Martin's Rose Bengal Agar medium (g lit-1): Glucose 10.0, peptone 5.0, $\mathrm{KH} 2 \mathrm{PO} 41.0, \mathrm{MgSO}_{4}$ $.7 \mathrm{H} 2 \mathrm{O} 0.5$, rose bengal 0.33 , agar 15.0 and distilled water $1000 \mathrm{ml}$. iii. ActinomycetesKen knight medium (g lit-1): $\mathrm{K}_{2} \mathrm{HPO}_{4}$ 1.0, $\mathrm{NaNO}_{3} \quad 0.1, \quad \mathrm{KCl} \quad 0.1, \quad \mathrm{MgSO}_{4} .7 \mathrm{H}_{2} \mathrm{O} \quad 0.1$, glucose 10.0and distilled water $1000 \mathrm{ml}$. The bacterial and fungal isolates were characterized based on their cultural, biochemical properties and microscopic appearances as described by Cheesbrough (2005).

\section{Estimation of nematode population}

Nematodes are usually unevenly distributed in the field especially in the forest soils Therefore, sampling was done in a random manner with an aim of collecting free living using hand shovel and auger. Samples of 250 g were collected at a depth 20 to $40 \mathrm{~cm}$ as the deep inside the drip line removing the top layer soil filled with dried leaves and other 
debris. Samples were collected in polythene bags, sealed, labelled and stored in a cool place in order to avoid desiccation of nematodes until processing. Processing soil samples was done by Cobb's (1998) Sieving and Decanting methods based on the difference in size and specific gravity between nematodes and other soil components using brass sieves of different mesh sizes.. Plastic beakers of capacity of 500 $\mathrm{ml}$ were processed through modified Baermann's method. Nematodes were recovered by Modified Baermann's Funnel Method (Schindler, 1961) and observed under stereo zoon microscope for further identification.

\section{Statistical analysis}

The experimental data emanated from the present investigation were subjected to statistical scrutiny in order to determine the treatment effect and other factors (Sukhatme and Amble, 1985)

\section{Results and Discussion}

\section{Bacteria}

The population of microbes was found to be affected in polluted soil which could be observed by increase in the bacterial population in the forest ecosystem especially in Kallar (78.5 x $\left.10^{8} \mathrm{CFU} \mathrm{g}^{-1}\right)$ and Ooty (74.75 x $10^{8} \mathrm{CFU}$ g-1) soil on compared to the Agroecosystem eastern block $\left(51.0 \times 10^{8}\right.$ CFU g-1) and polluted soil $\left(37.0 \times 10^{8} \mathrm{CFU}\right.$ g-1) in nearby town area. Significantly higher population of bacteria was noticed in soil near forest area (Table $1 \&$ 2, Fig. 1).

Among the seasons, soil sample taken from during pre-rainy $\left(S_{2}\right)$ and post- rainy $\left(S_{3}\right)$ shows more population in all ecosystem than sample taken during summer $\left(\mathrm{S}_{1}\right)$ and winter $\left(\mathrm{S}_{4}\right)$, the population rate was decreased in all ecosystem. In Kallar and Ooty forest area the sample taken during pre-rainy season, the mean bacterial population rate was $113.0 \mathrm{x}$ $10^{8} \mathrm{CFU} \mathrm{g}^{-1}$ and post- rainy season mean bacterial population rate was on par with each other (125.5 x $10^{8} \mathrm{CFU}$ g-1). This increase in the population of bacteria after raining may be due to the favourable microclimatic conditions viz., moisture content, temperature, active litter decomposition might have accounted for maximum bacterial action during post-rainy season. In addition to that the available phosphorous in kallar and Ooty forest area soil is 19.6 and 34.6 (kg/ha) respectively and this was evident from the analytical results of soil samples collected during post-rainy season.

Bacteria represent another important, though less explored, integral part of the microbial community in forest soils. For example, recent findings indicate that bacteria commonly harbor genes encoding plant cell wall-degrading enzymes (Berlemont and Martiny, 2015) and contribute significantly to the decomposition of organic matter (Štursová et al., 2012; Eichorst and Kuske, 2012; Lopez-Mondéjar et al., 2016; Brown and Chang, 2014 and Tian et al., 2014). In addition, bacteria are the major natural agents responsible for $\mathrm{N}$ fixation in forest ecosystems (Reed et al., 2011) and for other ecosystem processes, such as mineral weathering leading to the release of inorganic nutrients (Uroz et al., 2011). Similarly, Marcin et al., 2013, reported the diversity of soil bacteria (Chao1) in the studied soils was negatively affected by heavy metal pollution. Similarly to our results, Desai et al., (2009) reported decreased diversity of soil bacterial communities in long-term $\mathrm{Cr}$ polluted soils. Moffett et al., (2006) applied amplified ribosomal DNA restriction analysis and found that high $\mathrm{Zn}$ contents decreased diversity of bacterial communities in arable soils. 
The lower and higher bacterial population during pre-rainy seasons, might be due to differences in soil temperature. Among bacteria, Bacillus was dominant in all depths after rainy season in all ecosystem. Due to endospore forming capacity, the genus might have tolerated higher cold and thus proliferated heavily after raining. This might have been the possible reason for its greater number over actinomycetes. The lower and higher bacterial population during summer and pre-rainy seasons, respectively might be due to differences in soil temperature.

\section{Fungi}

The population of fungi in the Kallar forest areas was found to be higher than that of the other ecosystem which could be well established from their mean values of $134 \mathrm{x}$ $10^{5} \mathrm{CFU}$ g-1 soil, followed by Ooty forest ecosystem, Agro-ecosystem and polluted soil $\left(125,116.25\right.$ and $71.5 \times 10^{5} \mathrm{CFU}$ g-1) respectively. In the case of seasonal variation, the post rainy and winter season recorded higher value of $145 \times 10^{5} \mathrm{CFU}$ g- 1 soil followed by $112.5 \times 10^{5} \mathrm{CFU}$ g- 1 soil. In summer and pre-rainy, $79.25 \times 10^{5} \mathrm{CFU}$ g-1 soil and $110.25 \mathrm{x} \quad 10^{5} \mathrm{CFU} \quad \mathrm{g}-1$ soil respectively. In winter and post-rainy seasons were found to be on par and similarly prerainy and summer season were found to be on par. The combined effect of season and different ecosystem on the population of fungi was statistically non-significant. The highest mean fungi population of $134 \times 10^{5} \mathrm{CFU} \mathrm{g}^{-1}$ soil was observed in the post-rainy season under forest areas and the lowest mean value of $71.5 \times 10^{5} \mathrm{CFU} \mathrm{g}^{-1}$ soil was recorded in the under polluted soil near town areas. The fungal population was reduced in the polluted area compared to the forest ecosystem areas in comparison to the behavior of bacterial population. Since fungal spores are the main propagules for reproduction of fungi, elimination of spores in polluted summer and pre rainy would have reduced the total fungal population in soils (Table 1\&2, Fig. 2) (Kanagaraj et al., 2017).

Even though soils collected during winter harboured more number of fungi in polluted ecosystem, the difference between post-rainy and winter season was not significant. The fungal population was found to increase from the summer to winter season in ascending order which might be due to the return of favourable climatic conditions in the subsequent seasons. Singh, (1976) reported that the genera, in order of their frequency of isolation the genus viz., Penicillium, Mortierella, Oidiodendron, Fusarium, Aspergillus, Mucor, Alternaria, Chrysosporium, Cladosporium, Phialophora, Trichoderma, Rhizopus, Absidia, Aureobasidium, Cephalosporium, Colletotrichum, Cylindrocarpon, Cryptococcus, Monilia, Myrothecium, Phoma, Verticillium, Cunninghamella, Chaetomium and Rhizoctonia were found. Soils from well drained to moist areas yielded a higher number of fungal species than those from dry areas.

\section{Actinomycetes}

On comparative analysis, the actinomycetes population in this study area was found to be lower than that of bacteria and fungi. But, the forest areas recorded higher actinomycetes population than that of polluted ecosystem soil which could be noticed from their mean values of $42.5 \times 10^{2} \mathrm{CFU}$ g- 1 soil and $17.75 \mathrm{x}$ $10^{2} \mathrm{CFU}$ g-1 soil, respectively. The variation in the actinomycetes population among the kallar and Ooty forest area was on par with each other (Table $1 \& 2$, Fig 3).

Similarly, the seasonal influence on the actinomycetes population was observed to be significantly different. 
Table.1 Comparison of microbial population in the different ecosystem of forest soils of the Nilgiri forest with agro-ecosystem and polluted soil influenced by seasons

\begin{tabular}{|c|c|c|c|c|c|c|c|c|c|c|c|c|c|c|c|}
\hline \multirow{3}{*}{$\begin{array}{l}\text { Area (A) } \\
\text { Agro-Ecosystem } \\
\text { (Eastern block, } \\
\text { 11 }^{\circ} 00 ' 28.9 " N, \\
\left.7^{\circ}{ }^{\circ} 56^{\prime} 02.4 ' \mathrm{E}\right)\end{array}$} & \multicolumn{5}{|c|}{$\begin{array}{l}\text { Bacterial population } \\
\text { (X } \times 10^{8} \mathrm{CFU} / \mathrm{g} / \text { soil) }\end{array}$} & \multicolumn{5}{|c|}{$\begin{array}{l}\text { Fungal Population } \\
\text { (X x 10 } 10^{5} \mathrm{CFU} / \mathrm{g} / \text { soil) }\end{array}$} & \multicolumn{5}{|c|}{$\begin{array}{l}\text { Actinomycetes population } \\
\left.\text { (X x 10 } \text { 10 }^{2} \text { CFU/g/soil }\right)\end{array}$} \\
\hline & $\mathrm{S} 1$ & $\mathrm{~S} 2$ & $\mathrm{~S} 3$ & S4 & $\begin{array}{l}\text { Mean } \\
\text { (A) }\end{array}$ & $\mathrm{S} 1$ & $\mathrm{~S} 2$ & S3 & $\mathrm{S} 4$ & $\begin{array}{l}\text { Mean } \\
\text { (A) }\end{array}$ & $\mathrm{S} 1$ & $\mathrm{~S} 2$ & S3 & S4 & $\begin{array}{l}\text { Mean } \\
\text { (A) }\end{array}$ \\
\hline & 19 & 94 & 71 & 20 & 51.0 & 91 & 113 & 151 & 110 & 116.25 & 22 & 15 & 29 & 24 & 22.5 \\
\hline $\begin{array}{c}\text { Forest } \\
\text { ecosystem } \\
\text { (Kallar, } \\
\text { 11'19'54.1'N, } \\
\text { 76 }^{\circ} \text { 54'01.9''E) }^{\circ}\end{array}$ & 22 & 115 & 131 & 46 & 78.5 & 104 & 131 & 178 & 123 & 134.0 & 31 & 23 & 62 & 54 & 42.5 \\
\hline $\begin{array}{l}\text { Forest } \\
\text { ecosystem } \\
(\text { Ooty, } \\
11^{\circ} 41^{\prime} 43.7^{\prime \prime} \mathrm{N}, \\
\left.7^{\circ} 69^{\prime} 75.4^{\prime \prime} \mathrm{E}\right)\end{array}$ & 25 & 111 & 120 & 43 & 74.75 & 96 & 127 & 160 & 117 & 125.0 & 32 & 22 & 51 & 43 & 37.0 \\
\hline 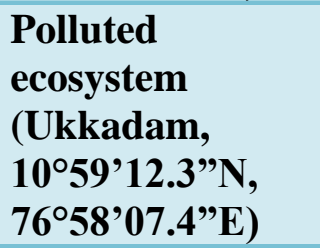 & 11 & 63 & 51 & 23 & 37.0 & 26 & 70 & 91 & 99 & 71.5 & 15 & 12 & 23 & 21 & 17.75 \\
\hline \multirow[t]{2}{*}{ Mean } & 19.25 & 95.75 & 93.25 & 33 & 60.31 & 79.25 & 110.25 & 145 & 112.25 & 111.69 & 25 & 18 & 41.25 & 35.5 & 29.94 \\
\hline & & & A & $\mathrm{S}$ & & & & A & S & & & & A & S & \\
\hline SEd & & & 2.88 & 2.75 & & & & 5.11 & 3.40 & & & & 1.05 & 1.87 & \\
\hline CD (0.05) & & & 6.6 & 6.3 & & & & 11.7 & 7.84 & & & & 2.43 & 4.32 & \\
\hline
\end{tabular}


Table.2 Microbial genera found predominantly in Nilgiri forest ecosystem in different season

\begin{tabular}{|c|c|c|c|c|c|}
\hline \multirow[t]{2}{*}{ S.No. } & \multirow{2}{*}{$\begin{array}{l}\text { Details of microbial genera in } \\
\text { collected soil sample }\end{array}$} & \multicolumn{4}{|c|}{ Sample analyzed in different season } \\
\hline & & S1 & $\mathbf{S 2}$ & S3 & S4 \\
\hline 1. & Bacillus & +++ & +++ & + & ++ \\
\hline 2. & Pseudomonas & +++ & ++ & + & ++ \\
\hline 3. & Alcaligens & ++ & + & + & +++ \\
\hline 4. & E. coli & ++ & ++ & ++ & +++ \\
\hline 5. & Azospirillum & ++ & ++ & +++ & +++ \\
\hline 6. & Acinetobacter & + & ++ & +++ & +++ \\
\hline 7. & Azotobacter & + & + & +++ & ++ \\
\hline 8. & Beijerinckia & ++ & + & +++ & ++ \\
\hline 9. & Derxia & + & + & ++ & + \\
\hline 10. & Flavobacterium & + & ++ & ++ & +++ \\
\hline 11. & Methylobacterium & ++ & +++ & ++ & ++ \\
\hline 12. & Xanthobacter & + & ++ & +++ & ++ \\
\hline 13. & Alcaligenes & + & + & ++ & + \\
\hline \multirow[t]{2}{*}{14.} & Paracoccus & + & + & + & +++ \\
\hline & Fungal genera & & & & \\
\hline 1. & Aspergillus flavus & ++ & + & +++ & +++ \\
\hline 2. & Aspergillus niger & + & + & +++ & +++ \\
\hline 3. & Fusarium & +++ & +++ & ++ & + \\
\hline 4. & Curvularia & ++ & ++ & +++ & ++ \\
\hline 5. & Penicillium & ++ & ++ & ++ & +++ \\
\hline 6. & Alternaria & ++ & + & +++ & +++ \\
\hline 7. & Rhizopus & ++ & + & ++ & ++ \\
\hline 8. & Trichoderma & + & + & +++ & +++ \\
\hline 9. & Phellinus & ++ & ++ & +++ & +++ \\
\hline 10. & Polyporus & + & + & +++ & +++ \\
\hline 11. & Daedalea & + & ++ & ++ & ++ \\
\hline 12. & Cladosporium & + & ++ & ++ & ++ \\
\hline 13. & Mortierella & ++ & + & ++ & +++ \\
\hline 14. & Rhizoctonia & ++ & + & ++ & +++ \\
\hline \multirow[t]{2}{*}{15.} & Acrostalagmus & + & ++ & +++ & +++ \\
\hline & Actinomycetes & & & & \\
\hline 1. & Streptomyces & + & ++ & +++ & +++ \\
\hline $\begin{array}{l}+ \\
++ \\
+++\end{array}$ & $\begin{array}{l}\text { pulation }<25 \times 10^{5} \mathrm{CFU} / \mathrm{g} / \text { soil } \\
\text { pulation }<50 \times 10^{5} \mathrm{CFU} / \mathrm{g} / \text { soil } \\
\text { opulation }<75 \times 10^{5} \mathrm{CFU} / \mathrm{g} / \mathrm{soil}\end{array}$ & & & & \\
\hline
\end{tabular}


Table.3 Different trophic groups of nematodes observed in the forest soil ecosystem

\begin{tabular}{|l|l|l|}
\hline S.No. & Trophic Level of Nematode & $\begin{array}{l}\text { Genus of Nematodes Identified } \\
\text { Rhabditis } s p . \\
\text { Acrobelus } s p . \\
\text { Acrobeloides } s p . \\
\text { Caenorhabditis } s p .\end{array}$ \\
\hline 2. & Bacterial feeding nematodes \\
\hline 3. & $\begin{array}{l}\text { Herbivorous nematodes or } \\
\text { Plant parasitic nematodes }\end{array}$ & $\begin{array}{l}\text { Helicotylenchus } s p . \\
\text { Psilenchus } s p . \\
\text { Longidorus } s p .\end{array}$ \\
\hline
\end{tabular}

Table.4 Comparison of Nematode population in the different ecosystem of forest soils of the Nilgiri forest with agro-ecosystem and polluted soil as influenced by seasons

\begin{tabular}{|l|c|c|c|c|c|c|c|c|c|c|}
\hline & \multicolumn{4}{|c|}{$\begin{array}{c}\text { Fungal feeding nematodes } \\
\text { (Nos. in 250 g soil) }\end{array}$} & \multicolumn{3}{|c|}{ Bacterial feeding nematodes } \\
(Nos. in 250 g soil)
\end{tabular}


Plate.1 Serial dilution to assess bacterial population

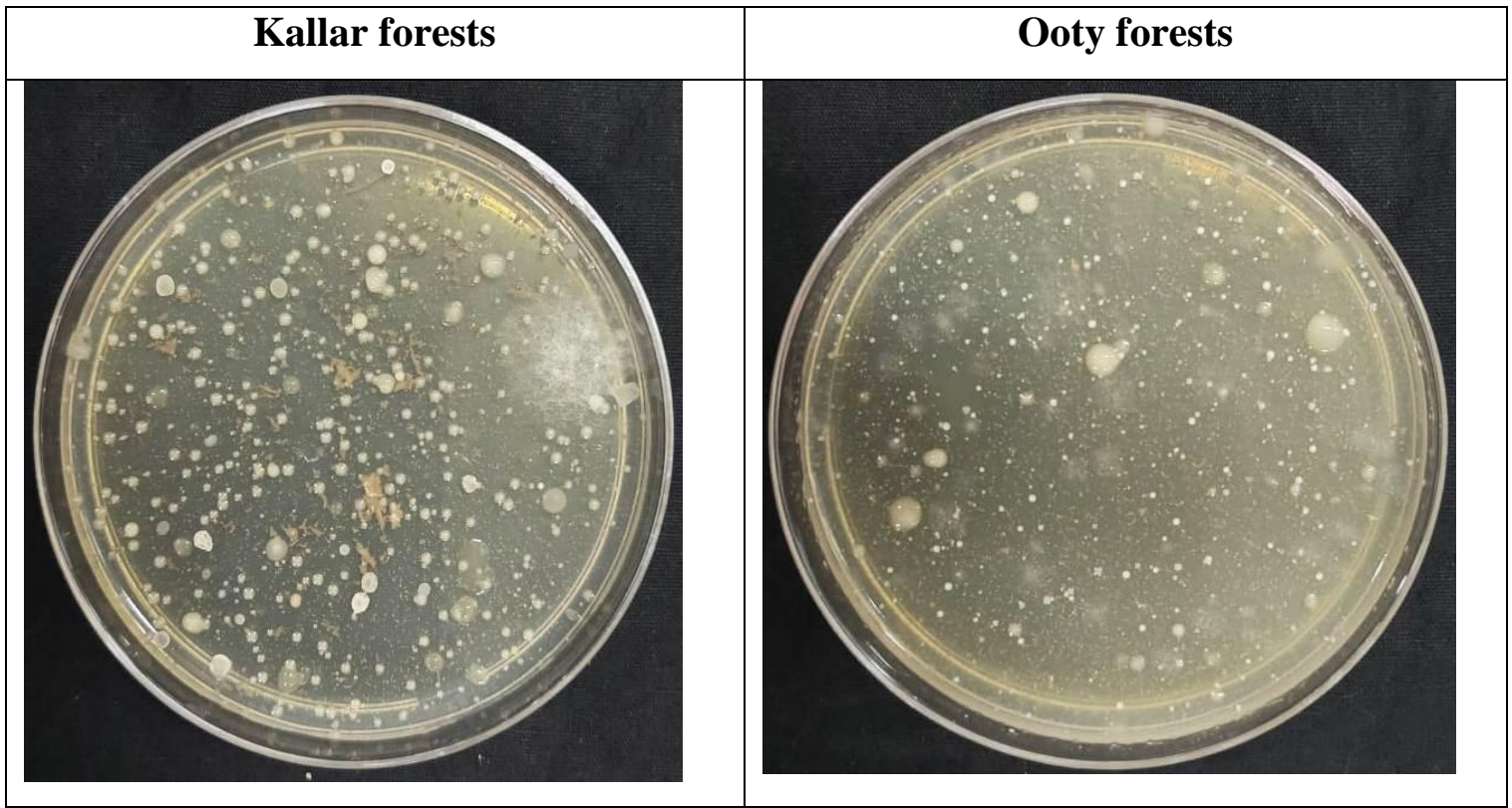

Plate.2 Serial dilution to assess bacterial population

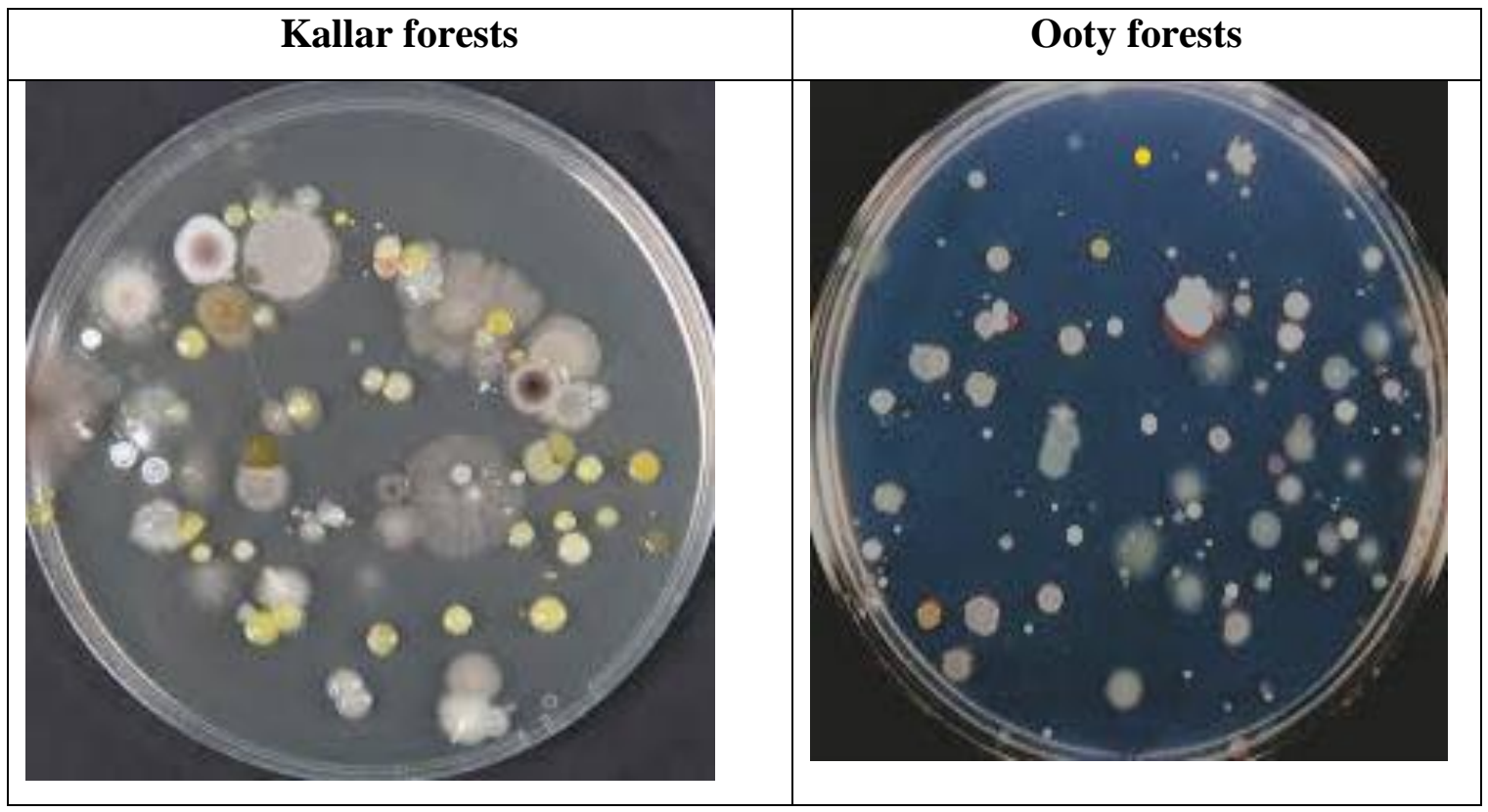


Plate.3 Serial dilution to assess Actinomycetes population

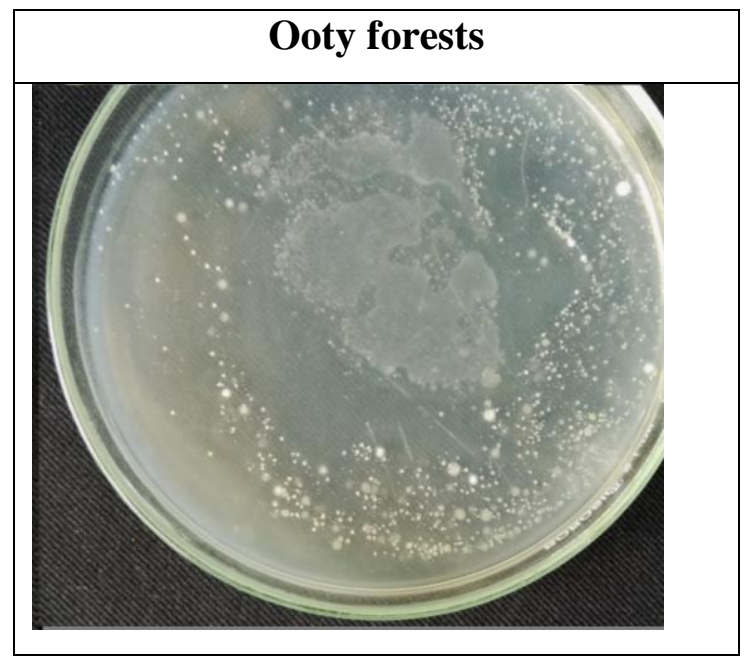

Plate.4 Bacterial and fungal feeding nematodes

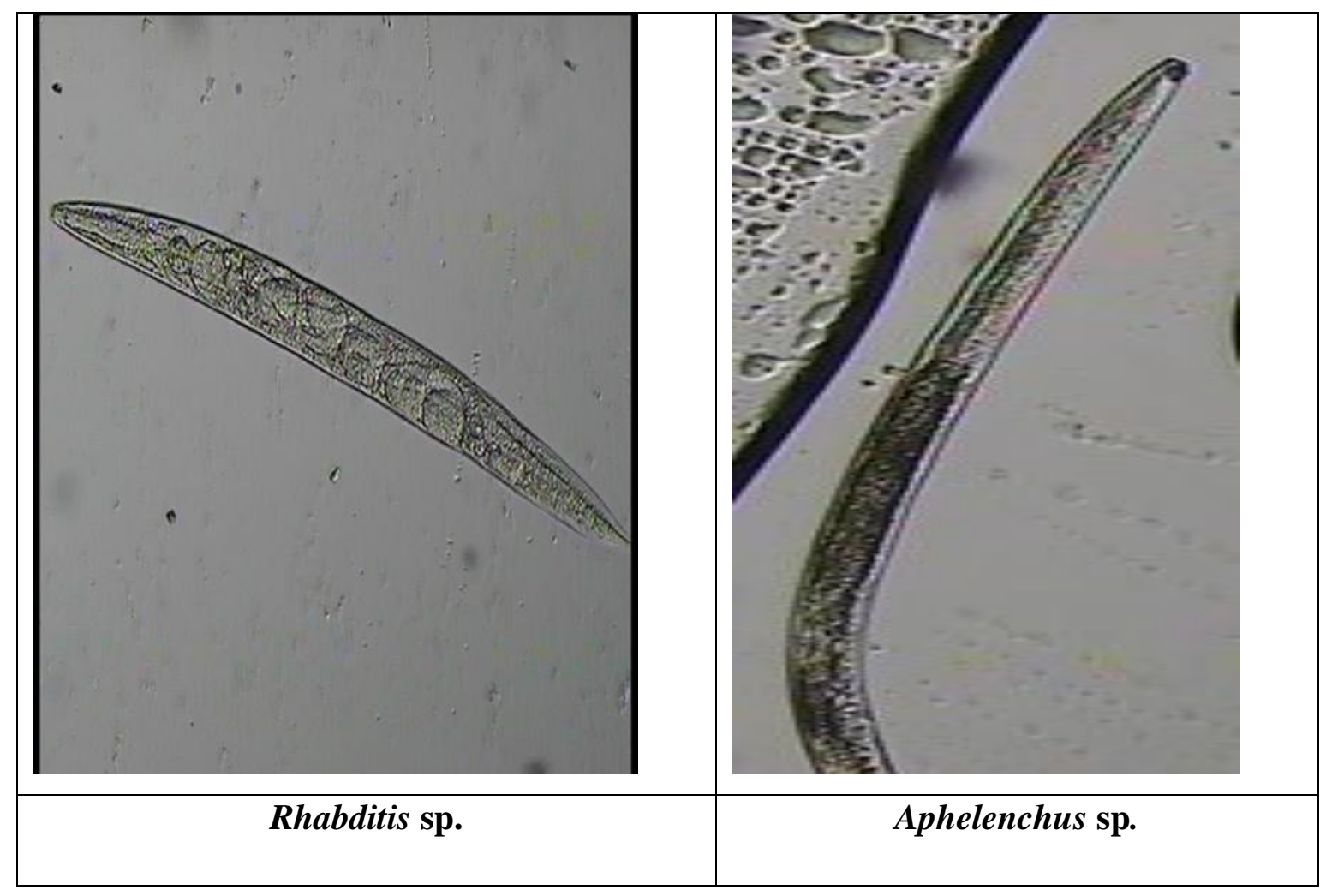


The highest mean value of $41.25 \times 10^{2} \mathrm{CFU}$ g-1 soil and of $35.5 \times 102 \mathrm{CFU}$ g-1 was recorded in post-rainy and winter seasons and the lowest mean value of $18 \times 10^{2} \mathrm{CFU}$ g- 1 soil was recorded in the pre-rainy season irrespective of the all ecosystem areas. The post-rainy (S3) and winter (S4) seasons were found to be on par and so was the case with summer (S1) and pre-rainy (S2) seasons. On the contrary, the interaction effect of ecosystem and season on actinomycetes population was observed to be nonsignificant. The highest mean value of $62 \mathrm{x}$ $10^{2} \mathrm{CFU}$ g-1 soil was noted in post rainy season under Kallar forest ecosystem area and the lowest mean value of $12 \times 10^{2} \mathrm{CFU}$ g- 1 soil were recorded in pre rainy seasons of polluted ecosystem near town area. In summer season, the actinomycetes population was found to be low due to adverse temperature and poor environmental condition and then the population increased during winter season due to the return of favourable environment. Similarly, Srivastava, (2002) reported that the actinomycetes population was higher during winter season when compared to all other seasons. The population of microbes got reduced heavily in polluted soil ecosystem (Golińska and Dahm, 2011).

As in the case of bacterial population, the actinomycetes population also recorded a significantly lower population in polluted ecosystem areas as compared to the forest areas due to the effect of unhealthy soil and decreased on spore formation. It is perceived that the heavy metals and toxin residue generated in the soil in the polluted ecosystem, this might have inhibited the spore formation and also eliminated beneficial microbes. However, it is anticipated that since sewage sludge, manures, and other organic materials will be applied to soil as fertilizer, the concentration of heavy metals may increase in soil (Lexmond and deHaan 1977;
Kobayashi 1985; Anzai and Matsumoto 1987; Iwasaki et al., 1990).

\section{Nematodes}

The population dynamics of fungal and bacterial feeding nematodes was influenced by the seasonal soil temperature and altitude. Fungal feeding nematode population in Ooty was more (129.75) when compared to Kallar (47.75 in $250 \mathrm{~g}$ soil) with soil having acidic $\mathrm{pH}$ due to leaching effect favored the growth of fungus and actinomycetes. Significantly higher population of bacterial feeding nematodes was recorded in lower altitudes of Nilgiris (121.5) in Kallar which resulted in higher rate of decomposition and in turn increased the organic carbon content where are the population decreased in the higher altitude (75.75). They enhance the decomposition process and nutrient mineralization due to release of excess nitrogen assimilated in the bacteria. Population of nematodes was lowest on the polluted soils which indicate the presence of toxic chemicals in the soil that reduced the population of beneficial nematodes (Table 3 \& 4, Fig 4).

A total of fourteen bacterial strains, fifteen fungal species and one actinomycetes were predominantly identified and isolated from Nilgiri forest ecosystem soils in summer, prerainy, post rainy and winter. Bacterial population found to be high in post rainy, winter and summer season. The population of Bacillus sp. and Pseudomonas sp.was more than $30 \times 10^{5} \mathrm{CFU} / \mathrm{g} /$ soil in summer season also (Table 3). Bacterial population was dominated by Bacillus, Pseudomonas, Alcaligens and E. coli. Most of the bacteria species can tolerate high temperature and survive in summer season. Aspergillus flavus, Aspergillus niger, Fusarium, Curvularia, Penicillium, Alternaria, Rhizopus and Trichoderma were the dominant fungal 
community found among the soil samples from these study sites. The number of microorganisms in the soil and their diversity depend on many factors, both biotic and abiotic ones (Schlegel 2000; Saadoun and Gharaibeh, 2003). Similarly, Munna et al., 2015 reported that the critical temperature (the temperature above which it is no longer possible to survive) of Bacillus spp. SUBB01 was estimated to be $53{ }^{\circ} \mathrm{C}$. The endospores are tough dormant structures that form inside the cell wall of certain types of bacteria, such as Bacillus bacteria. These tough capsules form in response to adverse conditions such as drought or high temperatures. They are also resistant to ultraviolet radiation, desiccation, extreme freezing, and chemical disinfectants.

The fungi genera (Acrostalagmus, Polyporus, Phelliinus, Trichoderma, Aspergillus spp., Alternaria) can survive in all seasons in a population of $<50 \times 10^{5} \mathrm{CFU} / \mathrm{g} /$ soil (Table 3). But in pre rainy season the species, Fusarium can available in a range of $20 \times 10^{5}$ $\mathrm{CFU} / \mathrm{g} / \mathrm{soil}$. Most of the fungal pathogens were available in winter and post rainy season (< $\left.75 \times 10^{5} \mathrm{CFU} / \mathrm{g} / \mathrm{soil}\right)$. Hence, the fungal spores cannot with stand high temperature compare to bacteria and actinomycetes. Cao et al., 2007 reported that the optimum temperature for growth of Penicillum marneffei is lies between $17-28^{0} \mathrm{C}$. Abrashev et al., 2015 reported that, temperatures above $30{ }^{\circ} \mathrm{C}$ lead to growth suppression and changes in morphological characteristics: decrease in the size of hyphal elements and increase in "active length" by switching from slightly branched long filaments to a multitude of branched forms.

Likewise fungi, actinomycetes can also survive in low temperature and high relative humidity. The only genus available in actinomycetes is Streptomyces. Akond et al., 2016 reported that normal growth and maintenance the temperature at a range of 25- $30^{\circ} \mathrm{C}$ are usually used for incubation of the great majority of Streptomyces, Nocardia, and Micromonospora. In most soils there are $10^{4}$ to $10^{7}$ colony forming units (CFU) of actinomycetes in 1 gram soil which constitutes $1-20 \%$ of the total number of microorganisms (Dahm et al., 1986; Shirokikh et al., 2002). Among them representatives of the Streptomycetaceae family, mainly the genus Streptomyces, make up $90 \%$ or even more of all actinomycetes.

Nematode population is directly linked with the soil health by being as good indicators. They play a major role in nutrient mineralization and mobilization. The bacterial feeders (Rhabditis sp, Acrobelus sp, saprophytes) and fungal feeders (Aphelenchus sp., Filenchus sp.) are found to be predominantly present in undisturbed forest soils collected. Acidic soil $\mathrm{pH}$ in Ooty was due to leaching effect which favoured the growth of fungus and actinomycetes that are food source of fungal feeding nematodes viz., Aphelenchus sp. Hence highest population of fungal feeding nematodes was recorded in Ooty forest soils. Similarly high bacterial population and bacterial feeding nematode population resulted in the increased rate of decomposition which in turn increased Organic Carbon content. The organic carbon content was high in Ooty which increased as the altitude increased i.e., from Kallar to Ooty. It is inferred from the study that the abundance of high bacterial and feeding nematodes in forest soils of hilly region contributed contribute for the nutrient mineralization and decomposition of organic matter than in the agricultural soils which are exposed high degree of human intervention. The occurrence of these beneficial nematodes is almost negligible due to the contamination of soil by industrial and city wastes.

In conclusion, it is inferred from the study that the abundance of high bacteria and fungi in forest soils of hilly region contributed for 
the nutrient mineralization and decomposition of organic matter than in the agricultural soils which are exposed high degree of human intervention. The occurrence of these beneficial fungi, bacteria, actinomycetes and nematodes is almost negligible due to the contamination of soil by industrial and city wastes. However, this study suggests that heavy metal in polluted soil also affects sensitive microorganisms such as fungi, bacteria, actinomycetes and nematodes at even lower concentrations. Microorganisms contribute to plant growth through various functions in soil. It is also understood that the quality of plant residues accumulating in these different forest sites are furthermore important and may play a vital role in soil microbial population. This microbial populations study at different forest types in the nilgiri forest ecosystem not proving information on microbial diversity, but also will provide information to explore the important microorganisms for various biotechnological application. Hence, by decreasing the dumping of agricultural chemicals and other industrial wastes in the soil the beneficial microbes can be conserved which play an indispensable role in the soil health and furthermore research should be carried out on the effects of heavy metals on soil microorganisms.

\section{Acknowledgement}

The authors are thankful to the State Forest Research Institute, Tamil Nadu Forest Department, Chennai for providing financial assistance to carry out the research work.

\section{References}

Abrashev R, Stoitsova SR, Krumova E, Pashova (2013) Temperature-stress tolerance of the fungal strain Aspergillus niger 26: Physiological and ultrastructural changes. World J Microbiol Biotechnol 30(5):
Anzai T, Matsumoto N (1987) Influences of continuous application of swine urine upon physical and chemical properties of paddy soil and rice growth. Effects of annual application of swine urine on the physicochemical properties and the heavy metal contents of paddy soil. Jpn. J. Soil Sci. Plant Nutr 58: 433-439

Bauhus J, Khanna PK (1999) The significance of microbial biomass in forest soils. In: Rastin, N., Bauhus, J.(Eds.), Going Underground -Ecological Studies in Forest Soils, Research Signpost, Trivandrum, India,pp.77-110.

Berlemont R, Martiny AC (2015) Genomic potential for polysaccharides deconstruction in bacteria. Appl Environ Microbiol81:1513-1519. doi:10.1128/AEM.03718-14.

Brown ME, Chang MC (2014) Exploring bacterial lignin degradation. Curr Opin Chem Biol 19:1-7. doi:10.1016/j.cbpa.2013.11.015.

Cheesbrough M (2005) District Laboratory Practice in Tropical Countries Part 2, UK, Cambridge University Press, Pp. 56, 6465,69-70

Costa OPM, Souza-Motta CM, Malosso E (2012) Diversity of filamentous fungi in different systems of land use. Agroforestry Sys $85,195-203$

Dahm H, Różycki H, Strzelczyk E (1986) Bakteriei promieniowce gleb i strefy korzeniowej drzew leśnych. Postępy Mikrobiologii 25: 103-120.

Desai C, Parikh RY, Vaishnav T, Shouche YS, Madamwar D (2009) Tracking the influence of long-term chromium pollution on soil bacterial community structures by comparative analyses of 16S rRNA gene phylotypes. Res. Microbiol. 160: 1-9.

Eichorst SA, Kuske CR (2012) Identification of cellulose-responsive bacterial and fungal communities in geographically and edaphically different soils by using stable isotope probing. Appl Environ Microbiol 78:2316-2327. doi:10.1128/AEM.0731311.

DeBruyn SM (1997) Explaining the 
environmental Kuznets curve: structural change and international agreements in reducing sulphur emissions. Environ Dev Econ 2(4):485-503

Faoro H, Alves AC, Souza EM, Rigo LU, Cruz LM, Al-Janabi SM, Monteiro RA, Baura VA. (2010) Influence of soil characteristics on the diversity of bacteria in the Southern Brazilian Atlantic Forest. App Environ Microbiol 76: 4744-4749.

Fan LF, Shieh WY, Wu WF, Chen CP (2006) Distribution of nitrogenous nutrients and denitrifiers strains in estuarine sediment profiles of the Tanshui River, northern Taiwan. Estuar Coast Shelf Sci 69: 543553.

Giller P (1996) The diversity of soil communities, the poor man's tropical rainforest. Biodivers Conserv 5(2):135168

Golinska P, Dahm H (2011) Occurrence of actinomycetes in forest soil. Dendrobiol 66: $3-13$

Hafich K, Perkins EJ, Hauge JB, Barry D, Eaton WD (2012) Implications of land management on soil microbial communities and nutrient cycle dynamics in the lowland tropical forest of northern Costa Rica. Trop Ecol 53: 215-224.

Iwasaki K, Yoshikawa G, Yoshida T (1990) Content of $\mathrm{Cu}, \mathrm{Zn}$, and $\mathrm{Cd}$ in greenhouse soils. Jpn. J, Soil Sci, Plant Nutr 61: 295297 (in Japanese)

Kanagaraj N, Kaleeswari RK, Tilak M (2017) Assessment of Soil Microbial Population in Thorn Forest and Moist Deciduous Forest, Western Ghats, Tamil Nadu. Int J Microbiol Res 9(9) :946-948

Kobayashi S (1985) Nouyouchi ni okeru dojochu no jukinzoku tou no chikuseki boushi ni kakawaru kanri kijun. Sangyo to Kankyo 14: 25-29 (in Japanese)

Lawton JH, Bignell DE, Bloemers GF, Eggleton P, Hodda ME (1996) Carbon flux and diversity of nematodes and termites in Cameroon forest soils. Biodivers Conserv 5: $261-273$

Lexmond, T.M. and deHaan, F.A.M. 1977: Implications of the use of $\mathrm{Cu}$ as a feed additive for pollution of soil. In Proc. Int. Semin. Soil Environ. Fertil. Manage. Intensive Agric Pp: 383-393

Lopez-Mondejar R, Zuhlke D, Becher D, Riedel K, Baldrian P (2016) Cellulose and hemicellulose decomposition by forest soil bacteria proceeds by the action of structurally variable enzymatic systems. Sci Rep 6:25279. doi:10.1038/srep25279.

Marcin C, ebiewski G, Marcin MorawskaPłoskonka, Justyna, Kuduk Katarzyna, Nikli nska, Maria (2013) Diversity of microorganisms from forest soils differently polluted with heavy metals. Appl Soil Ecol 64:7 -14

McGuire KL, Fierer N, Bateman C, Treseder KK, Turner BL (2012) Fungal community composition in neotropical rain forests: the influence of tree diversity and precipitation. Microb Ecol 63: 804-812

Moffett BF, Nicholson FA, Uwakwe NC, Chambers BJ, Harris JA, Hill TCJ (2006) Zinc contamination decreases the bacterial diversity of agricultural soil. FEMS Microbiol Ecol 43:13-19.

Muhammad Ali A, Nusrat J, Sultana N, Rahma $\mathrm{F}$ (2016) Effect of Temperature, $\mathrm{pH}$ and $\mathrm{NaCl}$ on the Isolates of Actinomycetes from Straw and Compost Samples from Savar, Dhaka, Bangladesh. American J Microbiology Immunology 1(2): 10-15

Munna MS, Tahera J, Nur IT, Noor R 2015. Survival of Bacillus spp. SUBB01 at high temperatures and a preliminary assessment of its ability to protect heat-stressed Escherichia coli cells. BMC Res Notes 8: 637.

Neher DA, Easterling KN, Fiscus D, Campbell CL (1998) Comparison of nematode communities in agricultural soils of North Carolina and Nebraska. Ecol Appl 8: 213223.

Parkinson D, Gray TRG, William ST (1971) Methods for studying the ecology of soil microorganisms, Oxford; Black Well Scientific Publications. Pp: 116

Ravikumar S, Fredimoses M, Gokulakrishnan R (2011) Biodiversity of actinomycetes in Manakkudi mangrove ecosystem, South 
west coast of India. Ann Biol Res 2: 76-82

Reed SC, Cleveland CC, Townsend AR (2011)

Functional ecology of free-living nitrogen fixation: a contemporary perspective. Annu Rev Ecol Evol Syst 42:489-512. doi:10.1146/annurev-ecolsys-102710145034.

Saadoun I, Gharaibeh R (2003) The streptomyces flora of Badia region of Jordan and its potential as a source of antibiotics active against antibioticresistant bacteria. J. Arid Environ. 53:365371.

Saravanan V, Santhi R, Kumar P, Kalaiselvi T, Vennila S (2013) Effect of Forest Fire on Microbial Diversity of the Degraded Shola Forest Ecosystem of Nilgiris Eastern Slope Range. Research J Agri Forestry Sci 1(5): $5-8$

Schlegel H (2000) Mikrobiologia ogólna. Warszawa:PWN.

Shirokikh IG, Zenova GM, Zvyaginstev DG (2002) Actinomycetes in the rizosphere of barley grown on acid soddy podzolic soil. Microbiol 71: 455-459.

Silva FS, Pereira DC, Nunez LS, Krepsky N, Fontana LF, Baptista Neto JA (2008) Bacteriological study of the superficial sediments of Guanabara Bay, RJ, Brazil. Braz J Oceanogr 56: 13-22.

Singh P (1976) Some fungi in the forest soils of Newfoundland. Mycologia 68 (4):881-890.

Somasundaram K (2005) Working plan (Part I, II and II) for the Nilgiris North Forest Division, Tamil Nadu Forest Department.
Srivastava RK (2002) Forest fire and biotic interference - A great threat to Nilgiri Biosphere, Indian Forester, 667-673

Stursova M, Zifcakova L, Leigh MB, Burgess R, Baldrian P (2012) Cellulose utilization in forest litter and soil: identification of bacterial and fungal decomposers. FEMS Microbiol Ecol 80:735-746. doi:10.1111/j.1574-6941.2012.01343.x

Sukhatme PV, Amble VN (1985) Statistical methods for agricultural workers (Rev. Edn.), ICAR, New Delhi

Tian JH, Pourcher AM, Bouchez T, Gelhaye E, Peu P (2014) Occurrence of lignin degradation genotypes and phenotypes among prokaryotes. Appl Microbiol Biotechnol 98:9527-9544. doi:10.1007/s00253-014-6142-4.

Uroz S, Oger P, Lepleux C, Collignon C, FreyKlett P, Turpault MP (2011) Bacterial weathering and its contribution to nutrient cycling in temperate forest ecosystems. Res Microbiol 162:820-831. doi:10.1016/j.resmic.2011.01.013.

Yeates GW (1987) Significance of developmental stages in the co-existence of three species of Mononchoidea (Nematoda) in a pasture soil. Biol Fert Soils 5:225-229.

Yeates GW, Wardle DA, Watson RN (1993) Relationships between nematodes, soil microbial biomass, soil microbial biomass and weed-management strategies in maize and asparagus cropping systems. Soil Biol Biochem 25: 869-876.

\section{How to cite this article:}

Kavitha, P.G., A. Sudha, P. Ahila Devi and Kumaran, K. 2020. A Comparative Study on Forest Soil Microbial Diversity and Biomass in Nilgiri Biosphere of Southern India. Int.J.Curr.Microbiol.App.Sci. 9(09): 3701-3715. doi: https://doi.org/10.20546/ijcmas.2020.909.457 